This is the final peer-reviewed accepted manuscript of:

Mengozzi, A., \& Miola, E. (2018). Paronomastic infinitives in north-eastern neoaramaic: A typological approach. Aramaic Studies, 16(2), 270-299. doi:

The final published version is available online at:

[https://doi.org/10.1163/17455227-01602006]

Rights / License:

The terms and conditions for the reuse of this version of the manuscript are specified in the publishing policy. For all terms of use and more information see the publisher's website.

This item was downloaded from IRIS Università di Bologna (https://cris.unibo.it/)

When citing, please refer to the published version. 


\title{
Paronomastic Infinitives in North-Eastern Neo-Aramaic: A Typological Approach
}

\author{
Alessandro Mengozzi \\ University of Turin, Turin, Italy \\ alessandro.mengozzi@unito.it \\ Emanuele Miola \\ University of Bologna, Bologna, Italy \\ emanuele.miola@unibo.it
}

\begin{abstract}
In the present article we aim to describe the distribution and functions of preposed and postposed paronomastic infinitives in literary and spoken varieties of North-Eastern Neo-Aramaic (NENA). In the first part, the syntax and the function(s) of constructions involving a paronomastic infinitive will be described from a typological point of view. Syntactic and functional variation of NENA paronomastic infinitives largely corresponds to what is found in other Semitic languages, as well as in many languages belonging to other families. In the second part of the article we will address the rendering of Biblical Hebrew and Classical Syriac paronomastic infinitives in NENA Bible translations and offer a survey of various constructions found in spoken varieties and in the language of early Christian Neo-Aramaic poetry.
\end{abstract}

\section{Keywords}

Bible translations - North-Eastern Neo-Aramaic- paronomastic infinitives- typology

\section{$1 \quad$ A Typological Sketch of Paronomastic Infinitives}

Paronomastic (or tautological) infinitives have already been discussed in a typological framework, ${ }^{2}$ sometimes with a specific focus and extensive reference to Semitic languages. ${ }^{3}$ In relation to preposed paronomastic infinitives alone, Bernini has offered a typological and pragmatic overview. ${ }^{4}$ The sketch proposed in this section

${ }^{1}$ While this article is the result of joint research, Alessandro Mengozzi is responsible for the final version of section 2, and Emanuele Miola for section 1. The conclusions have been written by both authors. Abbreviations: $\mathrm{ABL}=$ ablative; $\mathrm{ACC}=$ accusative; $\mathrm{AOR}=\mathrm{aorist} ; \mathrm{ARG}=$ argument(s); CAUS = causative; $\mathrm{C}$. = Christian (Neo-Aramaic dialect of $) ; \mathrm{CL}=$ clitic; COHORT = cohortative; $\mathrm{COND}=$ conditional; $\mathrm{CONN}=$ connective; $\mathrm{COP}$ = copula; $\mathrm{DAT}$ = dative; $\mathrm{DEP}=$ dependent; $\mathrm{DET}$ = determiner; $\mathrm{EMPH}=$ emphasis; FIN = finite; FOC = focus (marker); FUT = future; $\mathrm{GEN}$ = genitive; $\mathrm{GER}=$ gerundive; $\mathrm{HAB}=$ habitual; $\mathrm{IMP}=$ imperative; $\mathrm{INF}=$ infinitive; IPFV = imperfective; J. = Jewish (Neo-Aramaic dialect of $) ; \mathrm{M}=$ masculine; $\mathrm{NEG}=$ negative marker; $\mathrm{OBJ}=$ object; $\mathrm{OP}=$ operator; $\mathrm{PERF}=$ perfective; $\mathrm{PL}$ = plural; $\mathrm{POSS}=$ possessive; $\mathrm{PPT}$ = past participle; $\mathrm{PRED}=$ predicative particle; $\mathrm{PREP}=$ preposition; $\mathrm{PRESP}=$ present participle; $\mathrm{PRET}$ = preterite; $\mathrm{PROX}=$ proximative; $\mathrm{PRS}=$ present; $\mathrm{PST}=$ past; $\mathrm{PTCP}=$ participle; $\mathrm{RED}=$ reduplication; $\mathrm{REL}=$ relative; $\mathrm{SBJ}=$ subject; $\mathrm{SBJV}=$ subjunctive; $\mathrm{SG}=$ singular; $\mathrm{SoA}=$ state of affair; SUB = subordinator; TOP = topic (marker); $\mathrm{Vb}=$ verb; $\mathrm{VN}$ = verbal noun.

${ }^{2}$ T. Güldemann, I. Fielder and Y. Morimoto, 'The Verb in the Preverbal Domain across Bantu: Infinitive 'Fronting' and Predicate-centered Focus' (paper presented at the International Workshop BantuSynPhonIS: Preverbal Domains, ZAS Berlin and Humboldt University Berlin, 14-15 November 2014, https://www2.hu-berlin.de/predicate focus africa/data/2014-11-

14 Gueldemann The\%2overb\%2oin\%20the\%2opreverbal\%2odomain.pdf); J. Hein, 'Doubling and Do-support in Verbal Fronting: Towards a Typology of Repair Operations', Glossa: A Journal of General Linguistics 2/1 (2017), pp. 1-36 (3-7).

${ }^{3}$ G. Goldenberg, 'Tautological Infinitive', IOS 1 (1971), pp. 36-85; U. Rapallo, 'Tipologia dell'infinito paronomastico', Archivio Glottologico Italiano 56/1 (1971), pp. 105-127. See also E. Cohen's application of Goldenberg's model to Old Babylonian, with discussion of the bibliography on Akkadian paronomastic infinitives ('Paronomastic Infinitive in Old Babylonian', Jaarbericht "Ex Oriente Lux" 38 [2003-2004], pp. 105-112; Idem, 'The Old Babylonian Paronomastic Infinitive in -am', JAOS 126/3 [2006], pp. 425-432).

${ }^{4}$ G. Bernini, 'Constructions with Preposed Infinitive: Typological and Pragmatic Notes', in L. Mereu (ed.), Information Structure and Its Interfaces (Berlin: Mouton de Gruyter, 2009) pp. 105-128. 
attempts to combine previous typological approaches in a constructional perspective. Meaning-form pairings will be given for each type of paronomastic infinitive, with a tentative formalisation of the constructions at issue.

Paronomastic infinitives belong to the wider class of doubled verbs. Doubling is a syntactic process that involves repetition of phonological material beyond the boundaries of the word. Contrary to reduplication, adjacency of the doubled elements in the sentence is not mandatory. ${ }^{5}$ Moreover, doubling marks focus and intensification. More specifically, it marks predicate-centred focus, i.e., focus on the state of affairs or, alternatively, focus on the truth-value of the utterance. ${ }^{6}$

When verbal doubling comes into play, doublets including verbal nouns and non-finite forms (especially infinitives) are predominant in the languages of the world. This seems to be due to the ambiguous nature of forms such as infinitives and participles, which share properties with both nouns and verbs. ${ }^{7}$ As Ramat has said, 'INF può essere veramente considerato un nome verbale' ('the infinitive may indeed be considered a verbal noun') ${ }^{8}$ and it may therefore be involved in left- and right-dislocations such as those dealt with in this article.

\subsection{Preposed Infinitives}

As regards preposed paronomastic infinitives, ' $[\mathrm{m}]$ any languages tend to resort to inflected forms with the least amount of specification with respect to the major variables of speech act form and topic time, such as the infinitive forms. ${ }^{9}$ There are also minor types that make use of irregular infinitives or special morphology on the left-dislocated phrase. These constructions can be represented as follows:

$$
\begin{array}{cc}
\text { original VP } & \text { doublet VP } \\
{\left[(\{\mathrm{PREP}, \mathrm{CONN}, \mathrm{RED}\}) \mathrm{Vb} \mathrm{INF}_{\mathrm{IN}}(\text { special morphological marking })\right]} & +\quad\left[\mathrm{Vb} \mathrm{X_{ \textrm {FIN } }}\right]
\end{array}
$$

Function: predicate-centred focus or intensification

The label 'original' and 'doublet' are assigned following Jacob. ${ }^{10}$ One of the reasons the second VP cannot be the original is that in some languages the second VP may display a light or support verb, ${ }^{11}$ and such a verb must be classified as a doublet, since it does not bear the lexical information.

${ }^{5}$ See P. Jacob, 'On the Obligatoriness of Focus Marking: Evidence from Tar B'arma. The Expression of Information Structure', in I. Fiedler and A. Schwarz, A Documentation of Its Diversity across Africa, (Amsterdam/Philadelphia: John Benjamins, 2010), pp. 117-144; eadem, Doubled Verbs. Focus Marking in Sara-Bagirmi (paper presented at the Nilo-Saharan Linguistic Colloquium, University of Cologne, May 23, 2013, https://www.iaaw.hu-berlin.de/de/afrika/linguistik-undsprachen/veranstaltungen/afrikalinguistischeskolloquium/papers-wintersemester-2012-13/doubled-verbs.-focus-marking-in-sarabagirmi).

${ }^{6}$ T. Güldemann, 'Present Progressive vis-à-vis Predication Focus in Bantu: A Verbal Category between Semantics and Pragmatics', Studies in Language 27 (2003), pp. 323-36o. In a similar vein, as regards paronomastic infinitives in the Semitic languages, Y.-K. Kim, The Function of the Tautological Infinitive in Classical Biblical Hebrew (Winona Lake, IN: Eisenbrauns, 2009) pp. 111, 133, speaks of focus on 'the factuality of the proposition'. Gzella speaks of 'assertion' as 'the speaker's belief or conviction that the proposition is true' (H. Gzella, 'Emphasis or Assertion? Remarks on the Paronomastic Infinitive in Hebrew', BO 67/5-6, pp. 488-498 [492]).

${ }^{7}$ J.C. Moreno, 'O infinitivo flexionado em galego e em húngaro: um estudo contrastivo', Agália 4 (1985), pp. 457-462.

${ }^{8}$ P. Ramat, 'La natura dell'infinito', in H. Jansen, P. Polito, L. Schøsler and E. Strudsholm (eds.), L'infinito \& oltre. Omaggio a Gunver Skytte (Copenhagen: Odense University Press 2002) pp. 409-417 (409, our translation).

${ }^{9}$ Bernini, 'Constructions with Preposed Infinitive', p. 113.

${ }^{10}$ P. Jacob, 'Doubled Verbs. Focus Marking in Sara-Bagirmi', paper presented at the Nilo-Saharan Linguistic Colloquium, University of Cologne, 23 May 2013, p. 8.

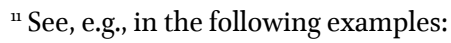

i. Sicilian (Italo-Romance, Indo-European; I.M. Mirto, 'Do-support in a Sicilian variety, an Italian pseudo-cleft, and the packaging of information', in L. Mereu [ed.], Information Structure and its Interfaces [Berlin: Mouton de Gruyter 20o9] pp. $153-168[153])$ babbiari fa joke.INF do.PRS.3SG 'He is only joking [contrary to (con)textual expectations]'. 
The only blocks necessary to the construction are those containing the verbal forms (see 1). Adverbs and arguments may be added to the original and/or to the doublet VPs (2-6). The same argument may appear both in the original and in the doublet VPs as a clitic in the doublet VP (7) or in both VPs (8).

(1) Biblical Hebrew (Semitic, Afro-Asiatic; Gen. 2.17)

Context: 'but you must not eat from the tree of the knowledge of good and evil, for when you eat from it you will certainly die'. (NIV)

$\begin{array}{ll}\text { mot } & \text { tämut } \\ \text { die.INF } & \text { die.FUT.2SG }\end{array}$

'you will certainly die'.

(2) Kabyle (Berber, Afro-Asiatic) ${ }^{12}$

'- Tesned taqbaylit? - Afham fehmey,

know.2SG the.Kabyle understand.vN understand.PRS.1SG

tiririt wer ttarray

answer.VN NEG answer.PRS.1SG

- Do you speak Kabyle?

- As for understanding it, I understand; but as for speaking it, I cannot'.

(3) Swahili (Bantu, Niger-Congo) $)^{13}$

kufa tu-ta-kufa wote

die.INF 1PL-FUT-die all

'We all shall die'.

(4) Russian (Slavic, Indo-European) ${ }^{14}$

$\begin{array}{lll}\text { znat' } & \text { ne } & \text { znaju } \\ \text { know.INF } & \text { NEG } & \text { know.PRS.ISG }\end{array}$

'I absolutely do not know'.

(5) Latin (Italic, Indo-European; Plauti Aulularia 181)

$\begin{array}{llll}\text { nunc } & \text { domum } & \text { properare } & \text { propero } \\ \text { now } & \text { house.ACC } & \text { hasten.INF } & \text { hasten. PRS.1SG }\end{array}$

'Now I'm making all haste to hasten home'.

(F. Leo's 1895 translation)

(6) Vietnamese (Viet-Muong, Austroasiatic) $)^{15}$

doc thi nonen doc sach

read TOP he should read book

'As for reading, he should read books'.

ii. Hausa (Chadic, Afro-Asiatic; M. Green, Focus in Hausa [Publications of the Philological Society, 40, Oxford: Blackwell, 2007] p. 6o)

$\begin{array}{lllll}\text { sàyé-n àbinci } & \text { nèe, } & \text { sukà } & y i \\ \text { buy.VN-GEN food } & \text { FOC } & \text { IPFV.DEP.3PL } & \text { do } \\ \text { 'They BOUGHT FOOD'. } & & \end{array}$

These constructions are not actually paronomastic, and so will not be further discussed in the article.

${ }^{12}$ Goldenberg, 'Tautological Infinitive', p. 6o, our spelling modifications.

${ }^{13}$ Rapallo, 'Tipologia', p. 111.

${ }^{14}$ Goldenberg, 'Tautological Infinitive', p. 72.

${ }_{15}$ T. Trinh, Edges and Linearization (Cambridge, MA: MIT dissertation, https://dspace.mit.edu/bitstream/handle/1721.1/68523/770761414MIT.pdf?sequence=2, 2011) p. $3^{8}$. 
(7) Spanish (Ibero-Romance, Indo-European $)^{16}$

$\begin{array}{lllllll}\text { leer } & \text { el } & \text { libro } & \text { Juan } & \text { lo } & \text { ha } & \text { leído } \\ \text { read.INF } & \text { the } & \text { book } & \text { Juan } & \text { OBJ.CL.3MSG } & \text { has } & \text { read }\end{array}$

'As for reading the book, Juan has indeed read it'.

(8) Piedmontese (Gallo-Romance, Indo-European $)^{17}$

Scriv-je, $\quad i \quad$ l'hai

write.INF-to.her/him SBJ.CL.1SG it.have.PRS.1SG

scrivù-je

written-to.her/him

'I really wrote to her/him. / As for writing to her/him, I did it'.

The paronomastic infinitive may be introduced by a preposition (9-10), a connective (11), or be reduplicated (12).

(9) French (Gallo-Romance, Indo-European $)^{18}$

Context: 'Somebody should read this article and take action, but who? And what should the action be?'

$\begin{array}{llllll}\text { Oh! Pour être lu, } & \text { ça serait } & \text { lu } \\ \text { Oh for } & \text { be.INF } & \text { read.PPT } & \text { this } & \text { be.COND.3SG } & \text { read.PPT }\end{array}$

'As for being read, it will be read'.

(10) Amharic (Semitic, Afro-Asiatic) $)^{19}$

əšši lä-madammät'-u onkw l-adamt'-əh

all.right for-listen.VN-DET PART PROX-1SG.listen.IPFV-2MSG.OBJ

[But listen to me Tiruneh.] 'All right, I'm listening'.

(11) Spanish (Ibero-Romance, Indo-European $)^{20}$

- Tu tío José tiene mucho dinero.

your uncle José have.PRS.3SG a.lot.of money

- Como tener-lo, lo tiene; pero es muy tacaño

as

have.INF-it it have.PRS.3SG but be.PRS.3SG very stingy

'- Your uncle José has a lot of money.

- As for having it, he has, but he is very stingy'.

(12) Spanish (Ibero-Romance, Indo-European) $)^{21}$

Comer comer no come mucho

RED eat.INF NEG eat.PRS.3SG much

'He doesn't really eat much'.

${ }^{16}$ L. Vicente, 'An Alternative to Remnant Movement for Partial Predicate Fronting', Syntax 12/2 (2009), pp. 158-191 (167).

${ }^{17}$ A. Aly-Belfàdel, Grammatica piemontese (Noale: Guin, 1933) p. 288, his translations.

${ }^{18}$ L. Malet, Les enquêtes de Nestor Burma et les nouveaux mystères de Paris (Paris: Laffont, 1985) vol. 2, p. 289, quoted in G. Bernini, 'Constructions with Preposed Infinitive', p. 123, his translation.

${ }^{19}$ O. Kapeliuk, Nominalization in Amharic (Wiesbaden: Franz Steiner, 1988) p. 68.

${ }^{20}$ L.A. Hernando Cuadrado, 'Sobre el funcionamiento de "como" en español', Revista de Filología Románica 19 (2002), pp. 325-340 (337).

${ }^{21}$ J. Valenzuela, J. Hilferty and M. Garachana, 'On the Reality of Constructions: The Spanish Reduplicative-topic Construction', Annual Review of Cognitive Linguistics 3 (2005), pp. 201-215 (208). 
The preposition pour in (9) and the connective como in (11), as well as thi in (6), function as topic markers. ${ }^{22}$

In some languages, infinitives placed before the finite verb may exhibit special morphological marking, including focus marking (see 16-18 and, perhaps, 15):

(13) Lithuanian (Baltic, Indo-European $)^{23}$

deg-tè dëga

burn-INF burn.PRS.3SG

'It burns brightly'.

(14) Turkish (Turkic) ${ }^{24}$

Ol-ma-sin-a ol-du, amma nasıl?

be-VN-3SG.POSS-DAT be-PAST but how

'Yes, it's done, but how?'

(15) Amharic (Semitic, Afro-Asiatic) $)^{25}$

mämţat-ass mäţtobbəňn näbbär

come.INF-FOC(?) come.PST.3SG to.me

'As to coming, he had come to me

[, but refusing I did send him back]'.

(16) Tuki (Bantu, Niger-Congo $)^{26}$

O-suwa owu Puta a-mu-suwa tsono raa

INF-wash FOC Puta SBJ-1SG-wash clothes her

'Puta WASHES her clothes'.

(17) Ama (Nyimang, Nilo-Saharan? $)^{27}$

$\begin{array}{lllll}\text { láda } & \text { bá } & \boldsymbol{n} \bar{\varepsilon} & \text { indù } & \text { ká ládī } \\ \text { walk.INF } & \text { EMPH FOC } & 3 \mathrm{SG} & ? & \text { walk.IPFV } \\ \text { 'She is WALKING'. } & & & \end{array}$

(18) Ewe (Kwa, Niger-Congo) ${ }^{28}$

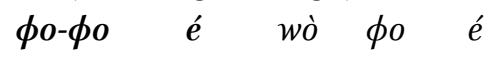

RED-beat FOC $3 \mathrm{SG}$ beat $3 \mathrm{SG}$

'S/he BEAT her/him'.

(19) Hungarian (Finno-Ugric, Uralic) $)^{29}$

vol-ni vol-t

be.PST-INF be.PST-3SG

'for being there, it was there'

${ }^{22}$ Pour is arguably the reduction of the French topic marker pour ce qui regarde/touche, see B. Combettes, 'Grammaticalisation des marqueurs de topicalisation en français : Les expressions du type pour ce qui regarde', Langue française 156/4 (2007), pp. 93-107.

${ }^{23}$ W. Meyer Lübke, 'Der intensive Infinitiv im Litauischen und Russischen', Indogermanische Forschungen 14 (1903), pp. 114-127 (114).

${ }^{24}$ Goldenberg, 'Tautological Infinitive', p. 6o, his translation.

${ }^{25}$ Ibid., p. 70.

${ }^{26}$ E. Biloa, Functional Categories and the Syntax of Focus in Tuki (Newcastle: Lincom Europa, 1997) p. 110.

${ }^{27}$ T. Güldemann, '(Preposed) Verb doubling and Predicate-centered Focus' (paper presented at the Workshop Project B7, Berlin, 21-22 November 2010), p. 2.

${ }^{28}$ F.K. Ameka, 'Focus Constructions in Ewe and Akan', MIT Working Papers in Linguistics, 17 (1992), pp. 1-25 (12).

${ }^{29}$ Goldenberg, 'Tautological Infinitive', pp. 72-73. 


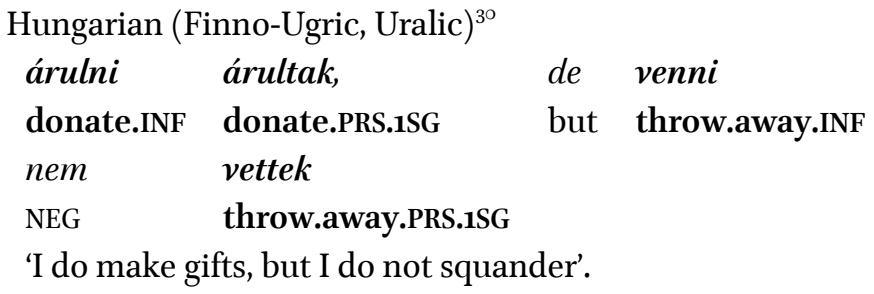

In (13), the 'second', unusual Lithuanian -tè infinitive is found, while in (14) 'the Turkish verbal noun in front position is also inflected for nominal categories, such as third person singular possessive and dative cases' ${ }^{3.1}$ In (18), the preposed verbal form is reduplicated. In Hungarian, as in other languages, along with regular tautologicalinfinitive constructions (20), special lexical morphology might be used in the original VP: the regular infinitive of 'be' would be lenni, but in (19) irregular vol-ni is used in order to reduplicate the verbal stem of vol-t.

Preposed paronomastic infinitives generally i) topicalise the lexical content of the verb and focus on the assertion contained in the second part of the sentence (i.e., the comment), which is given as true at the time of speaking, even contrary to co(n)textual expectation (see e.g., 2, 6, 7, 10-12)..$^{32}$ These constructions tend to be conventionally reanalysed as ii) truth-value focus constructions of the kind of [DOES Vb X]/[really $\mathrm{Vb} \mathrm{X}]($ see 1,3 , 5 , 9), which, in turn, may take on iii) an intensifying reading, such as those displayed by (4) and (13). All three readings are proposed for (8) in Aly-Belfàdel's grammar of Piedmontese.

Goldenberg maintains that preposed infinitives are not 'pan-glottic', ${ }^{33}$ but they are, in fact, well attested in various language families. These constructions are likely to emerge via dialogical interactions ${ }^{34}$ and occur especially in colloquial registers. Meyer-Lübke, on the other hand, says: 'zweifle aber nicht daran, dass [die Erscheinung] auch noch anderswo sich nachweisen lässt, sofern es eben überhaupt bis zur Bildung eines wirklichen Infinitivs gekommen ist. ${ }^{35}$ Recent typological research on different language families seems to support the latter claim. ${ }^{36}$

The construction in (21) seems to be less common in the languages of the world. Here, the infinitive is fronted as in a cleft, or cleft-like, sentence, and repeated by a cognate finite form in the following sentence. In the present article, only constructions formed by the infinitive followed by a relative pronoun or a subordinator will be considered as cleft(-like) sentences. Furthermore, these constructions may, but need not, exhibit a pre- or postverbal focus marker. Goldenberg says that these constructions are typical of Semitic languages, but one can also find them in other language families (see 23). ${ }^{37}$ Their function is linked, again, to focalisation (on the state-ofaffairs and, apparently, never on the truth-values of the utterance; see 21) and emphasis (e.g., mirativity in 22 and intensification in 23).

\footnotetext{
${ }^{30}$ Rapallo, 'Tipologia', p. 114.

${ }^{31}$ Goldenberg, 'Tautological Infinitive', pp. 6o-62; Bernini, 'Constructions with Preposed Infinitive', p. 113.

${ }^{32} \mathrm{~A}$ change in prosody may be responsible for the reanalysis of constructions focussing on the state of affairs (i.e. $[\mathrm{Vb} \mathrm{X}]_{\mathrm{FOC}}+[\mathrm{Vb}$ $\mathrm{X}(\mathrm{TAM})]_{\text {тор }}$ ) into truth-value focus constructions (i.e., [as for X $]_{\mathrm{rop}}+[\mathrm{Vb} \mathrm{X}]_{\mathrm{FоC}}$ ): see Güldemann, '(Preposed) Verb doubling', p. 6; Jacob, Doubled Verbs; cf. also Goldenberg, 'Tautological Infinitives', p. 72.

${ }^{33}$ Goldenberg, 'Tautological Infinitives', p. 58. Also Kim (The Function of the Tautological Infinitive, p. 112) is inclined to think that paronomastic infinitives are not frequently found outside the Semitic languages and, in the non-Semitic languages in which they do occur, such as the Romance languages they 'do not seem to be as productive as in $\mathrm{B}[\mathrm{iblical}] \mathrm{H}[\mathrm{ebrew}]$ '.

${ }^{34}$ See $(2,9,10)$, and E. Calaresu, 'Grammatica del testo e del discorso: dinamicità informative e origini dialogiche di diverse strutture sintattiche', in A. Ferrari, L. Lala and R. Stojmenova (eds.), Testualità. Fondamenti, unità, relazioni / Textualité. Fondements, unités, relations / Textualidad. Fundamentos, unidades, relaciones (Florence: Cesati, 2015), pp. 43-59.

${ }^{35}$ Meyer Lübke, 'Der intensive Infinitiv', p. 119.

${ }^{36}$ Güldemann et al., 'The Verb in the Preverbal Domain'.

${ }^{37}$ Goldenberg, 'Tautological Infinitive', p. 58.
} 
(21) Jewish Babylonian Aramaic (Semitic, Afro-Asiatic)

Context: 'If one intentionally took a false oath on a deposit and witnesses forewarned him...' should he be flogged, 'as this is the standard punishment for an intentional transgression' or rather bring a guilt-offering?

(Shebu. 37a-37b, The William Davidson Talmud).

$\begin{array}{lllllll}\text { milqē } & h u & d \text {-la } & \text { lqū } & a \underline{b} \bar{a} l & \text { qurbān } & \text { mēti } \\ \text { flog.INF } & \text { FOC } & \text { SUB-NEG } & \text { flog.PPT } & \text { but } & \text { offering } & \text { bring.PRESP }\end{array}$

'He is not indeed flogged, but rather brings an offering'. ${ }^{3}$

(22) Țuroyo (Semitic, Afro-Asiatic) $)^{39}$

$\begin{array}{llll}\text { nah̆̌nno } & b \text {-i-kaše } & \boldsymbol{i} \text {-h̆ăăyto } & \boldsymbol{d} \text {-h̆zeli } \\ \text { go down.PRET } & \text { in-DET-slope } & \text { DET-see.INF } & \text { SUB-see.PRET }\end{array}$

$\begin{array}{lllll}\text { kale } & \text { u-qămyon } & b \text {-filge } & d \text {-u-dărbo } & k a ̆ l y o \\ \text { there.it.is! } & \text { DET-truck } & \text { in-middle } & \text { of-DET-street } & \text { stop.PRET }\end{array}$

'Ich fuhr den Abhang hinunter. Mit schrecken sah ich plötzlich, dass der Lastwagen in der Mitte der Strae stand'.

(23) Kabyle (Berber, Afro-Asiatic $)^{40}$

d akras ay t-yekres

FOC tie.VN REL DET-tie.PST

'Il l'a bien noué'.

1.2 Postposed Infinitives

Postposed paronomastic infinitives are a special type of verbal echo-constructions. We could formally represent these constructions as

$$
\begin{array}{cc}
\text { original VP } & \text { doublet VP } \\
{\left[\mathrm{Vb} \mathrm{X}_{\mathrm{FIN}}\right]} & +[\ldots]+\left[(\mathrm{PREP}+) \mathrm{Vb} \mathrm{X}_{\mathrm{INF}}\right]
\end{array}
$$

Function: SoA and truth-value focus, intensification, frequentative

The bracketed ellipsis [...] represents any (group of) phrase(s) that can be added between the first and second part of the construction. Additionally, these constructions are typical of colloquial, informal speech.

As regards pragmatics and information structure, postposed paronomastic infinitives may also focus on the truth-value of the utterance (24-26), as is the case for the parallel construction with a preposed infinitive (see, e.g., 3 and 14 above). In cases such as (27-29) the focus seems rather to be on the state of affairs. In (30), the nuance of the utterance is that of unexpectedness and counter-expectation. The state-of-affairs conveyed by $[\mathrm{Vb} \mathrm{X}]_{\mathrm{FNN}}$ $[\mathrm{Vb} \mathrm{X}]_{\mathrm{NF}}$ takes place contrary to co(n)textual expectations.

${ }^{38}$ Ibid., p. $5^{2}$, translates: 'It is flogging that it is not flogged, but an offering he brings'.

${ }^{39}$ M. Waltisberg, Syntax des Țuroyo (Wiesbaden: Harrassowitz, 2016) p. 9o, his translation. Waltisberg describes this construction as a functional sub-category of the paronomasticher Relativsatz. It is in fact a cleft construction in which the fronted infinitive is usually preceded by the preposition $b$ - or, less frequently, by other prepositions and always by the definite article. The infinitive is then followed by the subordinator $d$ - and a finite verbal form of the same root. According to Waltisberg's Syntax (p. 88), the first function of this construction is to specify the exact temporal state of affairs of an action:

$$
\begin{aligned}
& \text { i. b-u-mătyo d-ătyo hiye-ste omur } \\
& \text { in-DET-Come.INF SUB-come.PRET he-also say.PRET } \\
& \text { 'Bei ihrem Kommen sagte (ihr Mann)' }
\end{aligned}
$$

Counter-expectedness seems, in fact, to be at stake in Waltisberg 's description of the second main function of the paronomastischer Relativsatz, i.e., to point out a surprising or frightening situation (p. 9o). When used with this function (e.g., in 19), the infinitive is not preceded by prepositions and verba videndi are frequently involved.

${ }^{40}$ Naït-Zerrad, Linguistique berbére, p. 134, his translation. $D$, a focus marker, is sometimes treated as a predicative particle. 
(24) North-Eastern Neo-Aramaic (Semitic, Afro-Asiatic; see 69, below)

$\begin{array}{lll}\text { men šmayyā } & \text { qrē-lēe } & \text { qrāy } y \bar{a} \\ \text { from heaven } & \text { call.PRET.him-3SG } & \text { call.INF }\end{array}$

'He did call him from Heaven/

He truly called him from Heaven'.

(25) Italian (Italo-Romance, Indo-European) ${ }^{41}$

Funziona, per funzionare

work.PRS.3SG for work.INF

'As for working, it does work'.

[but the point is another]'.

(26) Turkish (Turkic) ${ }^{42}$

Yet-er yet-me-sin-e

be.enough-AOR(3SG) be.enough-INF-3SG-DAT

ama, bura-dan nasıl çık-acag-ım?

but here-ABL how go_out-FUT-1SG

'Well they are enough, so far as being enough is the problem

(or: as to being enough they are enough), but how shall I get out of here?'

(27) Kenga (Bagirmi, Nilo-Saharan(?)) $)^{43}$

Context: - What are you doing? - Didn't you see?

$m-\bar{s} \bar{y} c \quad k$-̀̀̀̀c̀̀

1SG-SOW INF-SOW

'I'm SOWING'.

(28) Biblical Hebrew (Semitic, Afro-Asiatic; Gen 19.9)

häehāa bā lāgur wayyišpot šăfot

this one came foreigner judge.PRET.3SG judge.INF

'This fellow came here as a foreigner,

and now he wants to play the judge!' (NIV)

(29) Ancient Egyptian (Egyptian, Afro-Asiatic) ${ }^{44}$

Context: 'He shall not die, but he will live forever.'

nh-i 'nht

live-1SG living

'It is (in) living that I shall live'.

(30) North-Eastern Neo-Aramaic (Semitic, Afro-Asiatic; see 68 below)

mqutel-lay w-béd-lay qrābāa

fight.PRET-3PL and-do.PRET-3PL quarrel.INF

${ }^{41}$ http://forum.arduino.cc/index.php?topic=90134.0.

${ }^{42}$ From Aziz Nezin, quoted by Goldenberg 'Tautological Infinitive', p. 61, his translation.

${ }^{43}$ L. Neukom, Description grammaticale du kenga (langue nilo-saharienne du Tchad) (Köln: Köppe, 2010) p. 130.

${ }^{44}$ A. Shisha-Halevy, 'The "Tautological Infinitive" in Coptic: A Structural Examination', Journal of Coptic Studies 1 (1990), pp. 99-127 (114), his translation. 


$$
\begin{array}{llll}
l \bar{a} & \text { qru-lay } & \text { ell-āh } & \text { qrāb } b \bar{a} \\
\text { NEG } & \text { quarrel.PRET-3PL } & \text { on-her } & \text { quarrel.INF }
\end{array}
$$

'They fought and they quarreled,

but against her, they did not quarrel'.

Focus on truth value may also result in emphasis and intensification, which are the preferred reading when the first member of the construction is an imperative $(31,32)$ or a cohortative (33). In Biblical Hebrew ' $[t]$ he opposite sequence (infinitive-volitive) is unattested': $:^{4}$

(31) North-Eastern Neo-Aramaic (Semitic, Afro-Asiatic; see 64 below)

$\begin{array}{lll}w \text {-šabḥu } & \text { l-šemm-ēh } & \grave{s} a \bar{b} b o h \bar{e}^{-} \\ \text {and-praise.IMP } & \text { ACC-name-his } & \text { praise.INF }\end{array}$

'And do praise His name!'

(32) Biblical Hebrew (Semitic, Afro-Asiatic; Job 13.17)

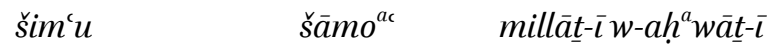

listen.IMP.2PL listen.INF word-my and-declaration-my

b-ozne-kem

with-ears-your

'Listen carefully to what I say; let my words ring in your ears'. (NIV)

(33) Biblical Hebrew (Semitic, Afro-Asiatic; Zech. 8.21)

nēlkāa hälok l-ḥallot $\quad$ et-pnēadonāy

go.COHORT.1PL go.INF to-entreat.INF before-the Lord

'Let us go at once to entreat the Lord!' (NIV)

While it is possible to speculate that such echo-constructions are widespread worldwide, Bernini argues that the restriction on the right position for dislocated infinitives 'may be a matter of typological variation' in the order of constituents. ${ }^{46}$

\section{Paronomastic Infinitives in North-Eastern Neo-Aramaic}

As Goldenberg observes ${ }^{47}$ Stoddard was the first to notice the use of paronomastic infinitives in Neo-Aramaic and their functional correspondence to the Hebrew and Classical Syriac constructions: "The absolute infinitive, joined with the finite verb, is used in the Modern as well as in the Ancient Syriac, and the Hebrew, to give intensity to the idea'. ${ }^{48}$ The first example he gives is a literal Neo-Aramaic rendering (35) of the Peshițtā of Jn 9.9 (34), where the Classical Syriac translator introduced a paronomastic infinitive to emphasise a contrastive opposition in the Greek original. This example shows that in the Syriac of the Peshițtā a paronomastic infinitive may idiomatically express intensification.

\footnotetext{
${ }^{45}$ J. Joosten, 'Three Remarks on Infinitival Paronomasia in Biblical Hebrew', in D. Sivan, D. Talshir \& C. Cohen (eds.), Zaphenath-Paneah. Linguistic Studies Presented to Elisha Qimron on the Occasion of his Sixty-Fifth Birthday (Beer Sheva: Ben Gurion University of the Negev, 2009) pp. 99-113 (106).

${ }^{46}$ Bernini, 'Constructions with Preposed Infinitive', p. 119.

${ }^{47}$ Goldenberg, 'Tautological Infinitive', p. 58.

${ }^{48}$ D.T. Stoddard, 'A Grammar of the Modern Syriac Language, as Spoken in the Oroomiah, Persia, and in Koordistan', JAOS 5 (1855), pp. 1-180 (167).
} 


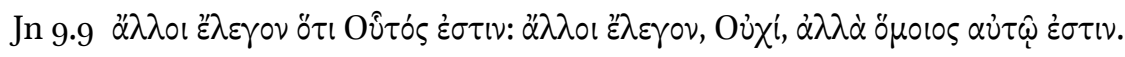

(34) Peshițtā of Jn 9.9

it d-ämrin (h)waw d-hu-yuw-it d-āmrin (h)waw:

'There were some who said that it was he and there were some who said:
lā, ellā medmā
dāmē
lēh
no, but resemble.INF resemble.PTCP.3SG him
"No, but he truly resembles him".

(35) Stoddard, A Grammar of the Modern Syriac Language, p. 167:

$\begin{array}{ll}\text { medmāya } & \text { bedmāy } \bar{a}-(y) l \bar{e} \\ \text { resemble.INF } & \text { resemble.GER-COP.3SG }\end{array}$

'He is very much like, he strongly resembles'.

(Stoddard's Eng. translation) ${ }^{49}$

Stoddard's second example (36) is not scriptural and attempts to reproduce an actual conversation:

(36) Stoddard, A Grammar of the Modern Syriac Language, pp. 167-168:

lā šmec-lēe?

NEG hear.PRET-3SG

'- Did he not hear?'

[Stoddard: 'To this, the answer may be as follows:']

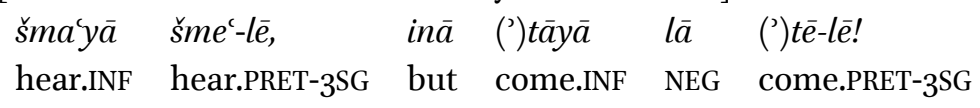

'- Hearing he heard, but coming he did not come'.

Following in Stoddard's footsteps, we will first check the idiomaticity of the Neo-Aramaic paronomastic infinitive in 'that refuge of lazy linguists' - i.e., Bible translations ${ }^{50}$ - and then look for syntactic forms and functions of constructions involving a paronomastic infinitive in more or less spontaneous colloquial speech and written literary texts.

\subsection{Paronomastic Infinitives in North-Eastern Neo-Aramaic Bible Translations}

The following table shows three different Christian Neo-Aramaic translations of twenty-seven constructions involving a paronomastic infinitive, as attested in the Hebrew text of Genesis. ${ }^{51}$ The transliteration reflects as

\footnotetext{
${ }^{49}$ Like the Greek original, other Neo-Aramaic translations do not have the paronomastic infinitive. See, e.g., the Translation of the Peshitta Version in the Suryoyo Language of Tur Abdin. Prepared in the Monastery of Mor Gabriel (Winfield, IL: Aramaic Bible Translation, 2013):

lo, elo kdome le

No, but resemble.PRS.3SG him

and both the Urmi Bible (New York 1893) and the 'Assyrian' translation accessible online (Aramaic Bible Translation, 2014; www.aramaicbible.org/assyrian.html):$$
\text { lā, ellā bedmāyā-ylè ellēh }
$$$$
\text { No, but resemble.GER-COP.3SG him }
$$

The 'Chaldean Neo-Aramaic' version expresses the contrastive opposition with another construction (Aramaic Bible Translation, 2015; www.aramaicbible.org/chaldean.html):
lā, ellā ilè hā de-kdāmē
No, but COP.3SG one REL-resemble.PRS.3SG him
'No, but he is one who resembles him'.

${ }^{50}$ C.P. Masica, Defining a Linguistic Area: South Asia (Chicago: University of Chicago Press, 1976) p. 13 o.

${ }^{{ }^{11}}$ The lists are based on the examples of Genesis, Joshua and Numbers discussed by Kim, The Function of the Tautological Infinitive, and may be incomplete. Nevertheless, they appear to be sufficient to show techniques and linguistic choices of the translators as far as paronomastic infinitives are concerned. Genesis and Joshua are the only books written in 'Classical Biblical Hebrew' (as defined in Kim, The Function of the Tautological Infinitive) that are available online in the Assyrian version. The language of the Jewish Neo-
} 
faithfully as possible the orthographies of the manuscript and of the printed texts. The references to verses in which the Hebrew Bible has the less common word order $\left(\left[\mathrm{Vb} \mathrm{X}_{\mathrm{FN}}\right]+\left[\mathrm{Vb} \mathrm{X}_{\mathrm{INE}}\right]\right)$ are marked with an arrow $\leftarrow$ in the tables.

The first Neo-Aramaic translation is drawn from an unpublished manuscript of the Dominican Friars of Mosul (DFM 4 , in the database of www.hmml.org), which displays in three columns, from right to left, the text of the Pešițā of Genesis, a translation in the Neo-Aramaic koine of the plain of Mosul, and an Italian translation that is possibly taken from the so-called 'Bibbia del Martini' (late 18th century). From around Gen. 30 onwards only the Neo-Aramaic text is given in a one-column page layout. Unfortunately, the manuscript is not dated, but it is reasonable to assume that the translation was prepared under the patronage of the Italian Dominicans who were active in Mosul and northern Iraq from $175^{\circ}$ and in the first half of the 19th century. Further research is needed to describe the language and translation technique of this fascinating trilingual Genesis. At first impression, one can say that it is based on the Pešițtā, with orthography and lexical choices far less classicising than those of the Urmi Bible, as is customary in the native manuscript tradition of northern Iraqi Christians.

The American Bible Society published the Urmi Bible in 1893 in New York. As is confirmed from Jn 9.9 and the examples discussed here below, it is based on the Greek text of the New Testament and the Hebrew Old

Testament. ${ }^{52}$ On the basis of Murre-van den Berg's thorough analysis, Khan underlines the classicising bias of the Neo-Aramaic translation of the Bible prepared by the American Protestants, as regards spelling, lexical choices and syntax. $^{53}$

The third and most recent Neo-Aramaic translation is part of a project that, more than a century after the publication of the Urmi Bible, aims to produce a text 'for Assyrian speakers of today' (http://www.aramaicbible.org/assyrian.html). Two American institutions appear to be involved in the project: the Aramaic Bible Translation (Winfield, IL) and the Assyrian Universal Alliance Foundation (Lincolnwood, IL). The constructions in which the paronomastic infinitive does not occur are in italics.

\begin{tabular}{|c|c|c|c|c|}
\hline Genesis & $\begin{array}{l}\text { Assyrian } \\
(2015)\end{array}$ & $\begin{array}{l}\text { Urmi Bible } \\
\text { (New York 1893) }\end{array}$ & $\begin{array}{l}\text { Trilingual } \\
\text { Genesis } \\
\text { Ms. DFM } 4 \text { (Plain } \\
\text { of Mosul, 18th- } \\
\text { 19th cent.) }\end{array}$ & $\begin{array}{l}\text { Eng. transl. of the } \\
\text { Hebrew text, based } \\
\text { on NIV }\end{array}$ \\
\hline 2.16 & $\bar{a} \underline{k} l \bar{e} t$ mē $\underline{k} u l t \bar{a}^{54}$ & mēk̄ālā ākllet & ik̄ālā iknol & You may eat \\
\hline $\begin{array}{l}2.17 \\
20.7\end{array}$ & $\begin{array}{l}\text { myātā bet } \\
\text { māytēt }\end{array}$ & $\begin{array}{l}\text { myātā bet } \\
\text { māytet }\end{array}$ & myāțā mmāyțet ${ }^{55}$ & You shall surely die \\
\hline 3.4 & $\begin{array}{l}\text { myātāā lē } \\
\text { māytiton }\end{array}$ & $\begin{array}{l}\text { myātāā lē } \\
\text { māytiton }\end{array}$ & $\begin{array}{l}\text { lā myāțāa } \\
\text { mmāytututu }\end{array}$ & $\begin{array}{l}\text { you will not certainly } \\
\text { die }\end{array}$ \\
\hline 15.13 & hwi ḥatitā & mided'yā id'et & idā'ā ido' & $\begin{array}{l}\text { Know for certain } \\
\text { (that...)! }\end{array}$ \\
\hline 16.10 & $\begin{array}{l}\text { mazyudē bet } \\
\text { mazyedennēh } \\
\text { zar'ak }\end{array}$ & $\begin{array}{l}\text { mazyudē bet } \\
\text { mazyeden l- } \\
\text { zar'āk }\end{array}$ & $\begin{array}{l}\text { mazodē bed } \\
\text { maziden l-zar'āk }\end{array}$ & $\begin{array}{l}\text { I will increase your } \\
\text { descendants }\end{array}$ \\
\hline 18.10 & $\begin{array}{l}\text { bet dāyrēn lkes } \\
\text { luk }\end{array}$ & $\begin{array}{l}\text { medārā bet } \\
\text { dāyren lkesluk }\end{array}$ & d'ārā bed dā'ren & $\begin{array}{l}\text { I will surely return to } \\
\text { you }\end{array}$ \\
\hline
\end{tabular}

Aramaic Targum by Sason ben Zakay Barzani (native of Rawanduz, near Erbil) mimics the syntax of Biblical Hebrew infinitives, including the paronomastic infinitives; see M. Rees, Lishan Didan, Targum Didan. Translation Language in a Neo-Aramaic Targum Tradition (Piscataway, NJ: Gorgias Press, 2008) pp. 48-49. The same is true for the Jewish Zakho versions of Genesis and Numbers (henceforth J. Zakho), published by Y. Sabar, Sefer Berešit be-aramit hadasha be-nivam šel yehude Zakho (Jerusalem: Magnes Press, 1983) and Sefer Bammidbar be-aramit hadasha be-nivam šel yehude Zakho (Jerusalem: Magnes Press, 1993). Exceptions to the rule of literal and mechanical rendering of the Hebrew construction in J. Zakho are given, here below, in the footnotes to relevant verses.

${ }^{52}$ H.L. Murre-van den Berg, From a Spoken to a Written Language: The Introduction and Development of Literary Urmia Aramaic in the Nineteenth Century (Leiden: Nederlands Instituut voor het Nabije Oosten, 'De Goeje Fund', 1999) p. 109.

${ }^{53}$ Murre-van den Berg, From a Spoken to a Written Language; G. Khan, The Neo-Aramaic Dialect of the Assyrian Christians of Urmi (Leiden: Brill, 2016) vol. 1, pp. 8-9.

${ }^{54}$ Noun used as a cognate object.

${ }_{55}$ The phonetic spelling of the manuscript, which reflects the assimilation of the future preverb $b e d-\sim b$ - to the first consonant of the verbal root, is corrected with a pencil notation: bed māytet.

${ }^{5}$ Pencil notation: bed māytutu. 


\begin{tabular}{|c|c|c|c|c|}
\hline 18.18 & $\begin{array}{l}\text { šarirā'it bet } \\
\text { hāwēe }\end{array}$ & $\begin{array}{l}\text { mehwāyā bet } \\
\text { hāwē }\end{array}$ & hwāyā bed hāwē & $\begin{array}{l}\text { He will surely } \\
\text { become }\end{array}$ \\
\hline $19 \cdot 9^{\leftarrow}$ & $\begin{array}{l}\text { bā'è d-hāwē } \\
\text { ellan dayyānāa }\end{array}$ & $\begin{array}{l}\text { me'bādā bet } \\
\text { 'abed diwān }\end{array}$ & $\begin{array}{l}\text { w-olē k-āwed } \\
\text { țālan šar' } \bar{e}^{57}\end{array}$ & $\begin{array}{l}\text { He wants to play the } \\
\text { judge }\end{array}$ \\
\hline 22.17 & $\begin{array}{l}\text { mbarukē bet } \\
\text { barkennuk } \\
\text { w-mazyudē } \\
\text { bet mazyeden } \\
\text { l-zar'uk }\end{array}$ & $\begin{array}{l}\text { mbārokē bet } \\
\text { barkennuk } \\
\text { w-mazyudē bet } \\
\text { mazyeden l- } \\
\text { zar'uk }\end{array}$ & $\begin{array}{l}\text { mbaroke bed } \\
\text { mbarkennuk } \\
\text { w-mazodē bed } \\
\text { maziden }\end{array}$ & $\begin{array}{l}\text { I will surely bless you } \\
\text { and make your } \\
\text { descendants ... } \\
\text { numerous }\end{array}$ \\
\hline 24.5 & $\begin{array}{l}\text { maderennēh } \\
\text { bronuk }\end{array}$ & $\begin{array}{l}\text { madurē maḍren } \\
\text { l-brunuk }\end{array}$ & $\begin{array}{l}\text { mad'orē } \\
\text { mad'ērē'n } \\
\text { bronuk }\end{array}$ & $\begin{array}{l}\text { Shall I then take your } \\
\text { son back? }\end{array}$ \\
\hline 26.11 & $\begin{array}{l}\text { māwtā bet } \\
\text { pā'ēš mumitāa }{ }^{58}\end{array}$ & $\begin{array}{l}\text { myāțā bet pāyeš } \\
\text { mumitā }\end{array}$ & $\begin{array}{l}\text { qțālā pāyeš } \\
\text { qțilāā }\end{array}$ & $\begin{array}{l}\text { He shall surely be put } \\
\text { to death }\end{array}$ \\
\hline $27 \cdot 30$ & be-plāțā yhwā & mplāṭā plețlē & ḱleṣle $\bar{e}^{60}$ & He has left \\
\hline $31.15^{\leftarrow}$ & 'kil lēh l-zuzē & $\begin{array}{l}\text { mēk̄ālā (')kellē l- } \\
\text { zuzan }\end{array}$ & kellē zuzan ${ }^{61}$ & $\begin{array}{l}\text { He has used up what } \\
\text { was paid for us (lit. } \\
\text { he has eaten our } \\
\text { money) }\end{array}$ \\
\hline 31.30 & $\begin{array}{l}\text { 'zālā ziluk̄ } \\
\text { maḥnuyē } \\
\text { muḥnē luk }\end{array}$ & $\begin{array}{l}\text { mēzālā (')zelluk } \\
\text { maḥnuwēē } \\
\text { muḥnēluk }\end{array}$ & [not found] & $\begin{array}{l}\text { You have gone off } \\
\text { You longed to return }\end{array}$ \\
\hline 37.8 & $\begin{array}{l}\text { malkutāà bet } \\
\text { 'abdèt'alan } \\
\text { yan šulțānā } \\
\text { bet 'ābodèt } \\
\text { 'alan }\end{array}$ & $\begin{array}{l}\text { me'baādā malkutāa } \\
\text { bet 'ab̄det } \\
\text { malkutāa elan } \\
\text { w-mhākomē bet } \\
\text { hākmet biyan }\end{array}$ & [not found] & $\begin{array}{l}\text { Do you intend to } \\
\text { reign over us? } \\
\text { Will you actually rule } \\
\text { us? }\end{array}$ \\
\hline $37 \cdot 10$ & bet ātah & mêtāyā bet ātāk & itāāyā bēd ātuk & $\begin{array}{l}\text { Will we actually } \\
\text { come? }\end{array}$ \\
\hline $\begin{array}{l}37 \cdot 33 \\
44.28\end{array}$ & $\begin{array}{l}\text { prāțā pišā ylē } \\
\text { prițā }\end{array}$ & $\begin{array}{l}\text { meprāṭā pišā } \\
\text { (y)lē prițā }\end{array}$ & tḅārā pešlē tbirīā & $\begin{array}{l}\text { He has surely been } \\
\text { torn to pieces }\end{array}$ \\
\hline $43 \cdot 3$ & $\begin{array}{l}\text { gzāmā gzim } \\
\text { lēh ‘alan }\end{array}$ & $\begin{array}{l}\text { meshād̄ā shedlēē } \\
\text { biyan hāw } \\
\text { (')nāšā }\end{array}$ & $\begin{array}{l}\text { shādāā mushedẹlē } \\
\text { bgāwan (h)āw } \\
\text { (')nāšā }\end{array}$ & $\begin{array}{l}\text { The man warned us } \\
\text { solemnly }\end{array}$ \\
\hline $43 \cdot 7$ & $\begin{array}{l}\text { buqerrē hāw } \\
\text { 'nāšā'alan }\end{array}$ & $\begin{array}{l}\text { mbāqorē } \\
\text { buqerrē hāw } \\
\text { (')nāšāà 'alan }\end{array}$ & $\begin{array}{l}\text { baqorē mbuqērē } \\
\text { (h)āw (')nāšā } \\
\text { ellan }\end{array}$ & $\begin{array}{l}\text { The man questioned } \\
\text { us closely }\end{array}$ \\
\hline 44.5 & $\begin{array}{l}\text { w-biyēh 'ābèed } \\
n e h{ }^{\prime} \bar{a} \bar{a}\end{array}$ & $\begin{array}{l}\text { me'bād̄ā kē ‘abed } \\
\text { neḥ̌šā biyēh }\end{array}$ & $\begin{array}{l}\text { w-ham fālā } \\
\text { kmāke } \bar{e} \text { bgāw } w \bar{a} h^{62}\end{array}$ & $\begin{array}{l}\text { He also uses (it) for } \\
\text { divination }\end{array}$ \\
\hline $46.4^{\leftarrow}$ & $\begin{array}{l}\text { w-ānā bet } \\
\text { ma'sqennuk }\end{array}$ & $\begin{array}{l}\text { mâsoqē bet } \\
\text { mâsqennuk }\end{array}$ & $\begin{array}{l}\text { w-ānā } \\
\text { bedmasqenno }^{63}\end{array}$ & $\begin{array}{l}\text { I will surely bring you } \\
\text { back again }\end{array}$ \\
\hline $5^{0.15}$ & pare'lan & $\begin{array}{l}\text { madurē māder } \\
\text { 'lan }\end{array}$ & pāre' lan & $\begin{array}{l}\text { (What if...) he pays } \\
\text { us back? }\end{array}$ \\
\hline
\end{tabular}

The Urmi Bible faithfully reproduces the syntax of the Hebrew Bible and has the paronomastic infinitive of the source text even in verses such as Gen. 19.9; 27.30; 31.15 and 46.4, in which the Classical Syriac Pešițā does not. The Mosul text is clearly based on the Pešițtā and accordingly does not use the paronomastic infinitives in these verses. The only other passage in which the Mosul text does not have the paronomastic infinitive of the Pešițtā and the Hebrew text is Gen. 44.5, in which the translator opts for what appears to be a local idiom and uses a word of ultimate Arabic origin ( $f a^{\prime} l$ ' augury, divination'). Arabic-derived šar'e for Syriac dinē in Gen. 19.9 and $k l e s ̦ l e \overline{~ f o r ~ n p a q ~}$

\footnotetext{
${ }^{57}$ Pešițtā: hā dā'en lan dinēe (noun used as a cognate object).

${ }^{5}$ Noun used as a cognate object.

${ }^{59}$ In J. Zakho myāsā māyəs, both infinitive and finite verbs are in the base form, with the intransitive meaning 'to die'.

${ }^{6 \circ}$ Pešițtā: $n f a q$.

${ }^{61}$ Pešițtā: eknal kaspan; J. Zakho: xalle ham ixālā.

${ }^{62}$ Pešițtā: āf mnaḥhāšūu mnaḥheš bēh.

${ }^{63}$ Pešițtā: w-enā esqāk̂; J. Zakho: masqannox ham masoqē.
} 
in 27.30 reveal the same non-classicising attitude of the author(s) of the Mosul translation as far as lexical choices are concerned.

As in Hebrew, an infinitive of the base form can also be placed before a passive verbal form, as in Gen. 26.11; 37.33 and $44.28 .{ }^{64}$

(37) Gen. 37.33 (Urmi Bible, 1893)

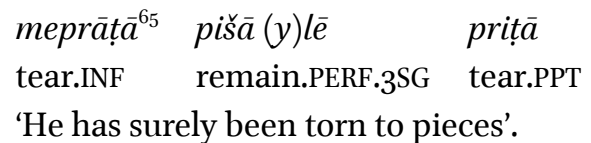

In 26.11, the Urmi Bible has the infinitive of the base form (intransitive meaning) joined with the passive future of the causative form (transitive meaning):

(38) Gen. 26.11 (Urmi Bible, 1893)

myātā bet pāyeš mumitā

die.INF FUT remain.SBJV.3sg CAUS.die.PPT

'He shall surely be put to death'.

In fifteen of the twenty-seven occurrences of the paronomastic infinitives listed above and in four of the five paronomastic infinitives attested in the book of Joshua (see below), the recent Assyrian version opts for other constructions: the infinitive is usually dropped altogether or, in two verses, replaced by a noun used as a cognate object (Gen. 2.16 and 26.11). This does not necessarily mean that the translator(s) of the American project perceive the paronomastic infinitive as non-idiomatic in Neo-Aramaic. They deliberately try to update the text to new standards and, as far as paronomastic infinitives are concerned, some choices seem to comply to Western speech habits and translation techniques (see, e.g., the use of 'to want' in Gen. 19.9 and adverbs and adverbial complements corresponding to 'truly, certainly, clearly' in Gen. 18.18; Josh. 9.24 and 23.13).

\begin{tabular}{|c|c|c|c|}
\hline Joshua & $\begin{array}{c}\text { Assyrian } \\
(2015)\end{array}$ & $\begin{array}{c}\text { Urmi Bible } \\
\text { (New York 1893) }\end{array}$ & $\begin{array}{l}\text { Eng. transl. of the Hebrew } \\
\text { text, based on NIV }\end{array}$ \\
\hline $7 \cdot 7^{+}$ & qām ma'beret & ma'burē mub’erruk & $\begin{array}{l}\text { (Why) did you ever bring } \\
\text { (this people) across (the } \\
\text { Jordan)? }\end{array}$ \\
\hline 9.24 & piš lēh mude'ā galyā'it & mad'uwē pešlē mude'yā & $\begin{array}{l}\text { They were clearly told (how } \\
\text { the Lord...) }\end{array}$ \\
\hline 23.12 & en hāwyā d-dāyritun & en medārā dayriton & But if you turn away \\
\hline 23.13 & $b$-šarirutā yād'iton & meda'yā ya'diton & You may be sure (that...) \\
\hline $24.10^{\leftarrow}$ & $\begin{array}{l}\text { barukēe burek lēh } \\
\text { elāwken }\end{array}$ & mbarokeē burkllē elāwknon & $\begin{array}{l}\text { He blessed you again and } \\
\text { again }\end{array}$ \\
\hline
\end{tabular}

In the verses in which the Hebrew Bible has the less common word order $\left(\left[\mathrm{Vb} \mathrm{X}_{\mathrm{FIN}}\right]+\left[\mathrm{Vb} \mathrm{X}_{\mathrm{INF}}\right]\right)$, the Urmi Bible usually normalises the word order to the more common construction with the paronomastic infinitive before the finite verbal form. This happens, for example, in Gen. 19.9; 31.15; 46.4 and Josh. 7.7, where the Pešițtā does not have paronomastic infinitives, as well as in Josh. 24.10; Num. 23.11 and 24.10, where the Pešițtā also has the infinitive placed before the verb. In Num. 11.15 and 16.13, however, where the Pešițtā closely follows the exceptional syntax of the Hebrew $\left(\left[\mathrm{Vb} \mathrm{X} X_{\mathrm{FN}}\right]+\left[\mathrm{Vb} \mathrm{X}_{\mathrm{INF}}\right]\right)$, the Urmi Bible does not have paronomastic infinitives at all. The postposed paronomastic infinitive would appear to be deemed ungrammatical by the translator(s) of the Urmi Bible, who

\footnotetext{
${ }^{64} \mathrm{Kim}$, The Function of the Tautological Infinitive, pp. 32, 39, 93.

${ }^{6}{ }_{5} \mathrm{An}$ anonymous reviewer suggests that the infinitive with prefixed $m e$ - may be a Syriacism for prātā.
} 
normalise the word order or suppress the postposed infinitive. At any rate, translators-including those of the Pešițta and the NIV ${ }^{66}$ - appear to be aware of and react to the different syntactic constructions of the source text. ${ }^{67}$

\begin{tabular}{|c|c|c|c|}
\hline Numbers & $\begin{array}{c}\text { Urmi Bible } \\
\text { (New York 1893) }\end{array}$ & Pešițtā & $\begin{array}{l}\text { Eng. transl. of the } \\
\text { Hebrew text, } \\
\text { based on NIV }\end{array}$ \\
\hline $11.15^{\leftarrow}$ & qțol li & qțolayn(y) meqțal & Go ahead and kill me! \\
\hline $16.13^{\leftarrow}$ & $\begin{array}{l}\text { 'abdet gānuḱ rēšā } \\
\text { 'alan }\end{array}$ & $\begin{array}{l}\text { ellā metrāwrbinin (')atton 'layn } \\
\text { metrāāwrābu }\end{array}$ & $\begin{array}{l}\text { And now you also want } \\
\text { to lord it over us! }\end{array}$ \\
\hline $\begin{array}{l}23.11^{\leftarrow} \\
24.10^{\leftarrow}\end{array}$ & barokēē bureklluk & mbarrāk̄u mbarrek att lhon & $\begin{array}{l}\text {... but you have done } \\
\text { nothing but bless } \\
\text { them! }\end{array}$ \\
\hline
\end{tabular}

The idiomatic status of paronomastic infinitives in literary Urmi Aramaic is confirmed by its use in the NeoAramaic works by Paul Bedjan (Khosrowa 1838; Cologne 1920). Goldenberg ${ }^{68}$ informs us that H.J. Polotsky had collected various examples in the writings of the Persian Lazarist, the self-proclaimed author of 'the most beautiful model of Neo-Aramaic style, ${ }^{69}$

\subsection{Paronomastic Infinitives in Spoken North-Eastern Neo-Aramaic}

As in Stoddard's examples and in the Bible translations, paronomastic infinitives usually precede the finite verbal form of the same root $\left(\left[\mathrm{Vb}_{\mathrm{INF}}\right]+\left[\mathrm{Vb} \mathrm{X}_{\mathrm{FN}}\right]\right)$ in the dialects described by Khan, who for paronomastic infinitive uses the term 'cognate infinitive'. ${ }^{70}$

In J. Urmia (39) the paronomastic infinitive gives focal prominence to the action in a typical contrastive construction, involving a negation.

(39)

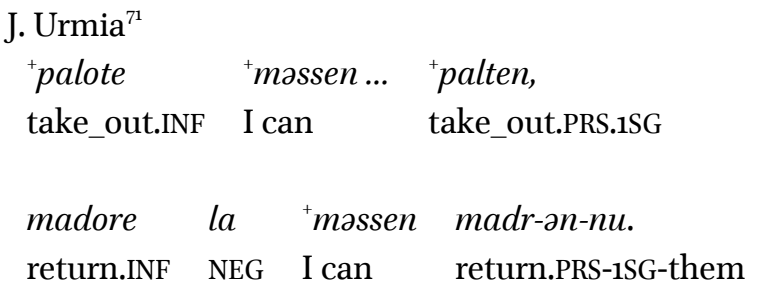

'I can take them out, but I cannot return them'.

In C. Urmi (40) a paronomastic infinitive may reinforce a positive polar question, expressing 'a desiderative bias, i.e. the speaker wants the answer to be 'yes". ${ }^{2}$

\footnotetext{
${ }^{66}$ The NIV translator(s) too would seem to seek more emphatic, perhaps idiomatic, English equivalents to the Hebrew marked construction (finite verbal form + infinitive).

${ }^{67}$ Gzella, 'Emphasis or Assertion?', p. 491, discusses the treatment of postposed paronomastic infinitives in Kim, The Function of the Tautological Infinitive, pp. 43-57. Joosten, 'Infinitival Paronomasia', pp. 105-109, shows that the postposed infinitive 'is but a conditioned variant of the normal sequence with a prepositive infinitive. The basic identity of the two variants is confirmed by their function. The postpositive infinitive has the same, or nearly the same, emphasizing effect as its prepositive counterpart', whereas 'with the pre-positive infinitive, there is often an element of contrast'.

${ }^{68}$ Goldenberg, 'Tautological Infinitive', p. 58.

${ }^{69}$ My translation of the French original quoted in H.J. Polotsky, 'Neo-Syriac Studies', JSS 6 (1961), pp. 1-32 (5).

${ }^{70}$ Khan's transcription systems have been simplified in minor details, especially as regards phonetic and suprasegmental features. Although prosody, intonation and pausing are relevant in the analysis of paronomastic infinitives and reduplication in general, a slightly simplified transliteration may suffice in the comparison of syntactic constructions as attested in actual speech and in written sources, where prosodic features are poorly represented or not recorded at all.

${ }^{71}$ G. Khan, The Jewish Neo-Aramaic Dialect of Urmi (Piscataway, NJ: Gorgias Press, 2008) p. 290.

${ }^{72}$ Khan, The Neo-Aramaic Dialect of the Assyrian Christians of Urmi, vol. 2, pp. 240 and 378.
} 
(40) C. Urmi

$\begin{array}{lll}\text { qabúla } & \text {-qàbli } & \text { 'árxə? } \\ \text { accept.INF } & \text { FUT-accept.SBJV.3PL } & \text { guests } \\ \text { 'Do they accept guests?' } & \end{array}$

In J. Sulemaniyya (41), the construction may connote the action as thoroughly completed, thus functioning as a telicity marker.

(41) J. Sulemaniyya ${ }^{73}$

'o zala-zill 'He went away'.

Discussing an occurrence of the same construction in J. Arbel (42), Khan points out the nominal nature of the infinitive, in that it may refer to a concrete entity (bšăla is both 'stew' and, at least formally, 'to cook'), ${ }^{74}$ and it syntactically behaves like a noun used as a cognate object ('to pray a prayer' in 43).

(42) J. Arbel ${ }^{75}$

bšāla bb-eu bašli-wa

cook.INF/stew with-it cook.3PL-HAB.PST

'They used to cook with it /

The stew, they cooked with it'.

(43) șlola șle-lan

prayer pray.PRET-1PL

'We prayed'.

Khan calls this construction in J. Sanandaj 'heavy coding' (44-45).

(44) J. Sanandaj ${ }^{76}$

šătoe šătena

drink.INF drink.PRS.1SG

'I am drinking'.

(45) kalba nwaxa nox

dog bark.INF bark.PRS.3SG

'The dog is barking'.

When the verbal form has the realis preverb $k^{-} \sim g-(46)$, this is also attached to the infinitive, as the first consonantal slot of I-weak verbal roots.

(46) kxole kəxna 'I am eating'.

gzala gezna 'I am going'.

\footnotetext{
${ }^{73}$ G. Khan, The Jewish Neo-Aramaic Dialect of Sulemaniyya and Halabja (Leiden: Brill, 2004) p. 324.

${ }^{74}$ Formally infinitives bšăla 'cooked food', 'ixāla 'to eat, food', 'food' and štă'a 'to drink, a drink' are nouns also in other dialects, as J. Koy Sanjaq: see H. Mutzafi, The Jewish Neo-Aramaic Dialect of Koy Sanjaq (Iraqi Kurdistan) (Wiesbaden: Harrassowitz, 2004) p.119. In C. Urmi the infinitive may be used as a cognate object, preceded by the indefinite article, to express intensity: e.g., xa-bəxya bəxyalo 'He wept bitterly' (lit. 'a weeping he wept'): see Khan The Neo-Aramaic Dialect of the Assyrian Christians of Urmi, vol. 2, pp. 239-240. The use of the indefinite article confirms the nominal nature of the infinitive in this construction.

${ }^{75}$ G. Khan, A Grammar of Neo-Aramaic. The Dialect of the Jews of Arbel (Leiden: Brill, 1999) p. 87.

${ }^{76}$ G. Khan, The Jewish Neo-Aramaic Dialect of Sanandaj (Piscataway, NJ: Gorgias Press, 2009) p. 332.
} 
The heavy coding usually marks the progressive aspect of a verbal form. This is probably the highest level of grammaticalisation that the construction with a paronomastic infinitive has reached in Neo-Aramaic (and Semitic?), from the pragmatic level of discourse prominence to a verbal paradigm with a specific aspectual connotation. It competes with other, more common explicit markers of progressive aspect such as the infinitive or gerund inflected with the copula and particles as $l a$ - or $l \bar{a} .{ }^{77}$

The same construction may also be used 'to express some kind of discourse prominence' with a verbal form that has habitual aspect. In (47) it expresses the surprise and merriment of the speaker about the fact that her neighbours dance around a little piece of bread and cheese.

\section{(47) g-ay-pút dăél naqòle naqlí baqèf}

'He drums on the tin and they dance to it'.

An extensive description of the meanings and functions of the cognate infinitive construction is found in Khan's grammar of C. Barwar. As for general functions, in this dialect paronomastic infinitives appear to operate on the discourse level and give prominence to the action expressed by the finite verbal forms or specify its characteristics. Khan further analyses prominence as: contrastive opposition (typically following a negation and a disjunctive conjunction: 48 and 55); a contrastive answer to a preceding question or, better, focus on the truthvalue of the predicate (49), as in Stoddard's second example (36); an unexpected situation (50 and $\left.5^{6}\right)$; the particular importance of an action in a narrative flow (with repetition of a verb used in the adjacent preceding cotext: $5^{1}$ ); and predicate-centred focus, the 'focus on the descriptive content of an action' in Khan's own terms: $\left(5^{2}\right)$ focuses on the truth-value of the action, whereas (57) focuses on the state of affairs of the predicate 'we would just say' (our emphasis).$^{78}$ Furthermore, a cognate infinitive may characterise the action as extensive and farreaching, thus functioning as an intensifier ( 53 and $\left.5^{8}\right)$, or as a slow action (54).

(48) b-qzța la mṣax doqaxle,'alla-qțala qațliwa naše

'In summer we could not catch them, but rather people would kill them'.

(49) zaqrituwa? zqara'i-zaqroxwa'axni, he.

'Did you knit? We indeed used to knit, yes'.

(50) praxla prixle?

'Has he [really] flown away?'

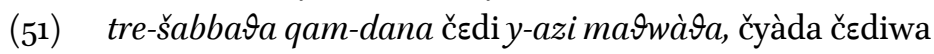

'Two weeks beforehand they would invite (people). They would go to the villages and give invitations'.

(52) 'ay lewa zwana zwanalla.

'They were not really buying it'.

(53) 'ana zala har-zilen biya

'I have absolutely gone with it (i.e. I am finished)!'

(54) šqúlta reše mattoye mtutalle l-ăra

'She took his head and slowly put it on the ground'.

In C. Barwar the infinitive may also be placed after the finite verb (55-58). As we shall see shortly, $\left[\mathrm{Vb} \mathrm{X} \mathrm{X}_{\mathrm{FN}}\right]+[\mathrm{Vb}$

$\left.\mathrm{X}_{\mathrm{INF}}\right]$ is the only word order that we find in C. Qaraqosh and early Neo-Aramaic poetry.

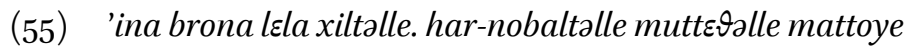

'But she did not eat the boy. She had just taken him and put him down'.

(56) 'Ega lanwa briva'ana braya.

'At that time I was not even born'.

(57) xàdexi 'ó-yoma hàtxa

be happy.PRS.1PL that day so

${ }^{77}$ See, e.g., Khan, The Jewish Neo-Aramaic Dialect of Sanandaj, pp. 89-9o.

${ }^{78}$ G. Khan, The Neo-Aramaic Dialect of Barwar (Leiden: Brill, 2008) pp. 730-732. 
yáni yamrèx-la màra

I mean say.PRS.1PL-it say.INF

'We were having fun. It was like that on that day, we would just say such things (but not really mean it)'.

(58) matrewa matroye xelana

'He was riding hard'.

Khan discusses also a C. Barwar case (59) in which the infinitive in the base form (intransitive meaning) is placed after a present tense in the causative form (transitive meaning) to express the telic outcome of an action:

(59) razza mbarzi braza

rice CAUS.dry.PRS.3SG dry.INF

'They dry the rice out'.

In C. Qaraqosh only postposed cognate infinitives are found. Khan describes them as adverbial constructions, 'used by speakers to draw particular attention to the activity expressed by a verb and signal that it has informational importance in the discourse. ${ }^{79}$ In the narrative of the material culture of the speakers, postposed infinitives seem to express repetition and continuity of a manual activity (6o and 61). In other cases (62 and 63), intensification and focus on the truth-value of the action may be involved.

(6o) kúllaha kxețíwa-lha bə-id̄ā, kxéți xyáta

all them sew.PST.3PL-them by-hand sew.PRS.3PL sew.INF

bə-'id̄a

by-hand

'They sewed them all by hand, they sewed them by hand'.

(61) 'u-hádax hawàka gzaqorwa zqàra

and-so weaver weave.PST.3SG weave.INF

'And so, the weaver would weave'.

(62) kəmódábəh̆la dabóha

slaughter.PRS.3SG-him slaughter.INF

'He slaughters him'.

(63) 'íd-i m'ubi-la flas-la

hand-my swell up.PRET-3SG be sprained.PRET-3SG

flàsa

be sprained.INF

'My arm swelled up and was sprained'.

\subsection{Paronomastic Infinitives in Early Christian Neo-Aramaic Poetry}

C. Qaraqosh and the language of early Christian Neo-Aramaic share a number of archaic morpho-syntactic features. ${ }^{80}$ It is also tempting to see the construction with a postposed paronomastic infinitive as a syntactic isogloss in the southernmost cluster of Iraqi Christian Neo-Aramaic dialects. As in C. Qaraqosh, in early Christian Neo-Aramaic poetry (17th century), we indeed find only the construction with a paronomastic infinitive placed after the finite verbal form as a resuming echo of the action expressed by the verb in sentence-final and verse-line final position.

${ }^{79}$ G. Khan, The Neo-Aramaic Dialect of Qaraqosh (Leiden: Brill, 2002) p. 359.

${ }^{80}$ A. Mengozzi, 'Neo-Aramaic Studies: A Survey of Recent Publications', Folia Orientalia 48 (2011), pp. 233-265 (242-243). 
In six of the nine occurrences of this construction, a prepositional object separates the finite verb from the infinitive. The prepositional object is either a pronoun or a noun with suffix pronoun.
w-šabḥu
l-šemm-ēh
šābohē
and-praise.IMP.PL ACC-name-his
praise.INF

'And do praise His name!' ( $\left.\mathrm{I}_{4} \mathrm{~b}\right)^{81}$

$w$-ǩ-māxsā trop l-sadr-āk $\quad$ trāpā

and-like-publican beat.IMP.SG ACC-breast-your beat.INF

$\begin{array}{lllll}d- & m \bar{a} w t \underline{a} \bar{a} & m t \underline{e} & e l l-\bar{a} \underline{k} & m t \bar{a} y \bar{a} \\ \text { because } & \text { death } & \text { come.PERF.3SG } & \text { on-you (f.) } & \text { come.INF }\end{array}$

'And like the publican do beat on your breast, because death has finally come to you!' (I1 35c-d)

māran bed dāyen-nēe dyānā

Our Lord FUT judge.SBJV.3SG-him judge.INF 'Our Lord will certainly judge him'. (J6 139d)

$$
\begin{aligned}
& \text { mquttel-lay }{ }^{82} \quad w^{-} \text {'bed } \underline{d} \text {-lay } \quad \text { qrā } \underline{b} \bar{a} \\
& \text { fight.PRET-3PL and-do.PRET-3PL quarrel.INF } \\
& \begin{array}{llll}
l \bar{a} & \text { qru-lay } & \text { ellāh } & \text { qrāáb } \bar{a} \\
\text { NEG } & \text { quarrel.PRET-3PL } & \text { on.her } & \text { quarrel.INF }
\end{array}
\end{aligned}
$$

'They fought and they quarrelled,

but against her, they did not quarrel'. (I2 71b-c) $)^{83}$

In (69) the object is represented by the $\emptyset$ marking of a 3 rd singular masculine object that is required by the cotext and thus in the English translation: 'Jesus Christ the Nazarene | called [him, i.e., St Paul] from heaven | and made [him] the first of His apostles'.

$$
\begin{aligned}
& \text { men šmayy } \bar{a} \quad \text { qrēele } \quad \text { qrāya } \\
& \text { from heaven call.PRET.him-3SG call.INF } \\
& \text { 'He truly called him from heaven'. (I2 21b) }
\end{aligned}
$$

In three occurrences of paronomastic infinitives, we do not find a prepositional object between the finite verbal form and the infinitive. In (70) the paronomastic infinitive seems to intensify the contrast between 'those who are truly believers' and 'produce fruit', the first two lines of the quatrain, and 'he who does not endure our Lord's words and even falls into apostasy', the second half of the quatrain:

\footnotetext{
${ }^{81}$ All references are to texts published and translated in A. Mengozzi (ed.), Israel of Alqosh and Joseph of Telkepe, A Story in a Truthful Language. Religious Poems in Vernacular Syriac (North Iraq, 17th Century) (CSCO, 589-59o, Leuven: Peeters, 2002).

${ }^{82}$ Mquttel- is written with $t \bar{a} w$ and $q u s ̌ s ̌ a y a \overline{~ i n ~ t h e ~ m a n u s c r i p t . ~ T h e ~ v e r b a l ~ r o o t ~ i s ~ r e p r e s e n t e d ~ a s ~} q t l$, as in Arabic orthography.

${ }^{8_{3}}$ The pronoun refers to the soul of the good: 'Every soul that they [evil ones and devils] see | they run towards and examine her. If she is from among them, they take her away. | The soul of a good one was brought. They fought and quarrelled, but they did not quarrel against her. | The soul of a bad one was brought. | As soon as she bowed before the Lord, | she was taken away and cast into their hands'.
} 
(70) Those who are truly believers produce fruit and bear hardship because of faith in our Lord. He who does not endure our Lord's words and falls into apostasy, his seed is without fruit even if it smells good.

$\begin{array}{lcll}o & d-\ldots & k \bar{a} p e r & k p a \overline{r a} \\ \text { DEM } & \text { REL } & \text { apostatise.SBJV.3SG } & \text { apostatise.INF } \\ \text { 'He who ... falls into apostasy...' } & (\mathrm{J6} 6 \text { 17c) }\end{array}$

In all the examples discussed so far, the infinitives are at the end of the verse line, where they serve as metrical fillers and sustain the end rhyme. They add two or three syllables to sentences that are complete in themselves and syntactically sound: šabḥu l-šemmēh! 'Praise His name!', men šmayya qrēlè ‘He called him from heaven', etc. In (6566) they form a nice parallelism in two consecutive lines.

Although the poetic nature of the text makes it rather difficult to grasp the nuances that the paronomastic infinitives actually add to these sentences, their functions appear to be similar to those found in the dialects discussed above. Used in combination with imperatives, as in (64) and (65), the infinitives seem to be intensifiers, while (67) and (69) may exemplify the focus on the truth-content of the action expressed by the finite verb. In (66), the infinitive appears to mark the action as thoroughly completed. In (68) the infinitive is used in a contrastive construction to stress the negation of the prepositional object of the verb and therefore a denial of what may be expected from the immediately preceding cotext, in which the same verbal root occurs.

Two occurrences of the verbal root 'ämed (71-72) are the only examples of paronomastic infinitives that are not placed at the end of a verse line. The finite verbal forms immediately precede the infinitival form ' $m \bar{a} \underline{d} \bar{a}$ 'to be baptised', that may also be interpreted as a noun ('baptism') ${ }^{84}$ and therefore as a cognate object rather than a cognate infinitive. The formally infinitive ' $m \bar{a} \underline{d} \bar{a}$ is not preceded by a prepositional object but followed by an attributive phrase, which confirms the interpretation of 'mā $\underline{d} \bar{a}$ as a noun and of the whole construction as a verb followed by a cognate object.

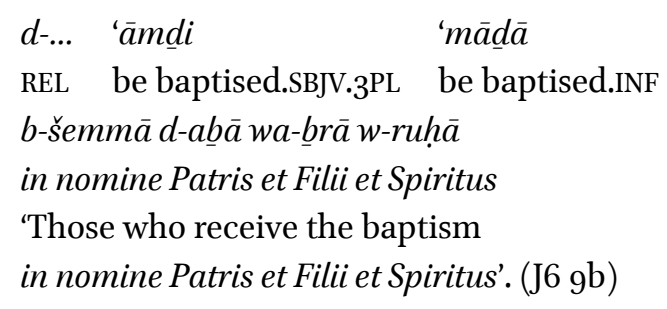
we-'med-lan
'mā $\underline{d} \bar{a}$
da-mših̨a
and-be baptised.PRET-1PL be baptised.INF GEN-Christ

'And we were baptised in the baptism of Christ'. (J6 1ob)

The cognate object typically functions as syntactical support for an attribute, which in these cases specifies that it is a Christian baptism. Together with the attribute, it functions as an adverbial modifier: 'to receive a Christian baptism' suggests 'to be baptised the Christian way', in the same way: 'to live a happy life' suggests 'to live happily'.

\footnotetext{
${ }^{84}$ Both the infinitive of the base form 'mād $\underline{d} \bar{a}$ 'to be baptised, receive the baptism' and the noun ma'moditāa, that derives from the causative form ma'mode 'to baptise, give the baptism', mean 'baptism' and can be used as nouns.
} 


\section{Provisional Conclusions}

In most NENA dialects preposed paronomastic infinitives may be used to express the functions that are commonly associated with this type of construction across languages, namely, focus on the state of affairs (e.g., 19, 57) and the truth-value (e.g., 10, 25, 52) of the proposition (often in contrast to what might be expected from the context), also intensification or emphasis (e.g., 3, 9) and continuity/repetition of an action. In the latter meaning, it is even grammaticalised in a J. Sanandaj verbal paradigm that expresses progressive aspect (44-46).

In most NENA varieties, including the language of the Urmi Bible, only preposed paronomastic infinitives are found. Typological research on the paronomastic infinitives and our data suggest that this is a general tendency: languages that display $\left[\mathrm{Vb} \mathrm{X}_{\mathrm{INE}}\right]+\left[\mathrm{Vb} \mathrm{X}_{\mathrm{FN}}\right]$ may (but do not have to) display $\left[\mathrm{Vb} \mathrm{X}_{\mathrm{FIN}}\right]+\left[\mathrm{Vb} \mathrm{X}_{\mathrm{INF}}\right]$. As a matter of fact, however, only in C. Barwar do we find both preposed and postposed paronomastic infinitives, both of which have similar functions.

There seem to be fewer varieties that display only $\left[\mathrm{Vb} \mathrm{X} X_{\mathrm{FN}}\right]+\left[\mathrm{Vb} \mathrm{X} \mathrm{XNF}_{\mathrm{IN}}\right]$ constructions. In C. Qaraqosh and in the language of early Christian Neo-Aramaic poetry, only postposed paronomastic infinitives occur. In NENA varieties in which paronomastic infinitives are allowed or even mandatorily placed after the finite verb, they seem to be preferred to express intensification rather than predicate-centred focalisation. As in Biblical Hebrew, only postposed infinitives are attested with imperatives. 